\title{
Political Socialization Media of Selayar Islands General Election
}

\author{
Andi Gau Kadir ${ }^{1 \mathrm{a}}$; Nurlinah ${ }^{1}$; Rahmatullah ${ }^{1}$ \\ ${ }^{1}$ Department of Politics and Government, Hasanuddin University, Makassar, Indonesia \\ acCorresponding author: gau_kadir@yahoo.com
}

\begin{abstract}
This paper aims to identify the most influential political socialization media in shaping the political culture of maritime communities in the Selayar Islands District. The research method used is a combination of quantitative and qualitative methods with data collection methods in the form of surveys, interviews and document studies. Data analysis uses quantitative analysis in the form of cross-tabulation of data and qualitative analysis. The results showed that there was no significant political socialization media in the socialization of elections. Recorded public attention to election wardens only about $34 \%$. Of the $34 \%$ of respondents who pay attention to the election, the mass media still holds the greatest role in influencing the public in paying attention to the discourse around the election. The least influence in the form of citizens' attention to the election discourse is the family.
\end{abstract}

Keywords-general election, political socalization, selayar island, marine community

\section{INTRODUCTION}

This research is a follow-up research from Research on the behavior of maritime community voters in Pangkajene and Kepulauan Islands and Selayar Islands Regency. The results of the study explained that voter participation in elections in two maritime districts in South Sulawesi depends on the variant of the general election. The level of participation of pilpres, election, election of bupati and legislative election always vary. For example, the participation rate of 2014 presidential election is very low whereas in legislative and bupati elections the level of participation is high. This striking difference is due to factors of emotional closeness and mobilization of voters to participate to opt for a more intense vote. The most affecting level of participation is proximity to the candidate. Whether it is the proximity of a village or family closeness, either with a direct candidate, or a winning team [1].

The behavior preferences of selecting community groups based on livelihoods in the two districts can be grouped into six categories. First, use the consideration of the successful team / punggawa. Second, pragmatic / incentive considerations. Usually the most prominent is money politics. Third, the campaign issue. Fourth, the identification of figures (figure Identification). Fifth, the identification of political parties (party Id), although still quite small, 13\% in Selayar and 15\% in Pangkep. Keenan, group solidarity. The most prominent is due to the choice of other family members. In conclusion, each community in these two districts have characteristics similar to each other [1].

Factors that include the most decisive maritime community in choosing candidates and candidates or political parties are sociological factors, psychological (2 factors) and rational factors (3 factors). In the sociological factors, the choice of family and the origin of the region to be the main reference. On psychological factors, the relationship with the party is the reason, but very little is found. On rational factors, beliefs about future performance, vision, mission and job program and candidate's ability [1].

The behavior of voters in local elections in maritime areas leads more to the character of political party figures. Political parties are only considered as vehicles and symbols as complementary requirements. In addition, many voters are still influenced by money politics. This reality happens precisely because candidate candidates are using the money so it becomes a culture in every election [1].

In the context of the development of democracy in Indonesia, what concludes in the above study is certainly quite worrisome. Democracy is actually built on the rationality of society but the reality that there is actually showing the opposite trend. Although the rate of community participation in elections is at the highest level in South Sulawesi, the underlying awareness is still more dominant in emotional and pragmatic closeness. It is therefore interesting to examine how the processes of political socialization can form such awareness-awareness in society in Kepualaun Selayar. Based on the aforementioned background, the purpose of this study is to find out what socialization media is most influential in the general election of maritime community in Selayar Islands District?

\section{RESEARCH METHOD}

This study uses a combined method of quantitative and qualitative. Quantitative method by spreading the survey to 50 people at random while qualitative method is done by interview and observation. The study was conducted in Selayar District in July 2017. Data analysis used quantitative analysis in the form of frequency tables and cross-tabulation of data for subsequent interpretation and qualitative data analysis through reduction, interpretation and conclusion. 


\section{RESUlT AND DISCUSSION}

\section{A. Profile of Respondent}

Based on the age range, between 17-20 years as many as 2 people, $21-30$ as many as 21 people, $31-40$ as many as 15 people, $41-50$ as many as 10 people, and over 50 years as many as 2 people. Based on sex, 36 men and 14 women. Based on the residence of the island as many as 22 people and on land as many as 28 people. Based on educational background: no school 1 person, elementary and equal 20 people, junior high school and equal 11 people, high school and equal 2 people, and college 16 people. Particularly for the background distribution of respondents based on sub-district where respondents live can be seen in the following table:

TABLE I. PROFILE OF RESPONDENT

\begin{tabular}{|l|r|}
\hline \multicolumn{1}{|c|}{ District Name } & Number of Respondents \\
\hline Kepulauan Selayar & 1 \\
\hline Pasimarannu & 8 \\
\hline Pasilambena & 0 \\
\hline Pasimassunggu & 5 \\
\hline Takabonerate & 2 \\
\hline Pasimassunggu Timur & 2 \\
\hline Bontosikuyu & 11 \\
\hline Bontoharu & 1 \\
\hline Benteng & 15 \\
\hline Bontomanai & 0 \\
\hline Bontomatene & 3 \\
\hline Buki & 2 \\
\hline Total & $\mathbf{5 0}$ \\
\hline
\end{tabular}

\section{B. Public Attention to Election}

Based on the respondent's answer to the answer of whether they follow the development of the discourse about the election, the answers are obtained as many as 8 people or $16 \%$ of all respondents who answered always, 9 people or $18 \%$ of all respondents who answered often, 19 people or $38 \%$ of all respondents answer rarely and the rest 14 people or $28 \%$ of all respondents who answered never. If parsed more detail and associated with the type of work of respondents then obtained the following information:

TABLE II. PUBliC ATtention to ELECTION

\begin{tabular}{|l|c|c|c|c|}
\hline \multirow{2}{*}{ Profession } & \multicolumn{4}{c|}{ Intensity of Attention to Election } \\
\cline { 2 - 5 } & Always & Often & Rarely & Never \\
\hline Midwife & & 1 & & \\
\hline Housewife & & & 1 & \\
\hline College student & & 1 & 1 & \\
\hline Fishermen & & 2 & 8 & 8 \\
\hline Merchants & & & 3 & 4 \\
\hline Sailors & 1 & & 1 & 2 \\
\hline Entrepeneur & 1 & & & \\
\hline Civil servants & 2 & 3 & 2 & \\
\hline The Informal Sector & 4 & 2 & 1 & \\
\hline Driver Total & & & 2 & \\
\hline \multicolumn{1}{|c|}{} & 8 & 9 & 19 & 14 \\
\hline
\end{tabular}

The table above shows that fishermen, traders and sailors pay the least attention to election discourse while the civil servants and the informal sector pay the most attention to election discourse.

Based on the background, it is seen that the higher the education the attention to the election also tends to be higher. More information is presented in the following table:

TABLE III. Public AtTention to Election

\begin{tabular}{|c|c|c|c|c|}
\hline \multirow{2}{*}{ Level of Educations } & \multicolumn{5}{|c|}{ Intensity of Attention to Election } \\
\cline { 2 - 5 } & Always & Often & Rarely & Never \\
\hline No School & & & & 1 \\
\hline Elementary & & 1 & 10 & 9 \\
\hline Junior High School & 1 & 2 & 5 & 3 \\
\hline Senior High School & & & 1 & 1 \\
\hline High Shool & 7 & 6 & 3 & \\
\hline Total & 8 & 9 & 19 & 14 \\
\hline
\end{tabular}

From the table it can be seen that the respondents whose level of education is the majority of the universities pay attention to the election while the respondents with high level of elementary and equal education almost all answered rarely and never follow the development of the election.

\section{Political Socialization Media of Election}

To reveal more about the phenomenon of public attention to the election then described how the environment respondents pay attention to the election. The environment in question here is the family environment, the environment, and the school / workplace of the respondent. The results of our interviews are summarized in the following table:

TABLE IV. POLITICAL SOCIALIZATION MEDIA OF ELECTION

\begin{tabular}{|c|c|c|c|c|}
\hline \multirow{2}{*}{ Media/Agents } & \multicolumn{4}{|c|}{ Intensity of Attention to Election } \\
\cline { 2 - 5 } & Always & Often & Rarely & Never \\
\hline Family & 4 & 9 & 27 & 10 \\
\hline Surrounding environment & 3 & 14 & 21 & 12 \\
\hline School / Workplace & 3 & 11 & 25 & 11 \\
\hline Average & $\mathbf{3}$ & $\mathbf{1 1}$ & $\mathbf{2 4}$ & $\mathbf{1 1}$ \\
\hline
\end{tabular}

From the above data shows that there is a tendency of respondent's environment to influence the level of respondent's attention to the election discourse. Nevertheless, there is a striking difference in the answers always to every environment when compared with the respondents' attention level. On average only 3 respondents whose surroundings always pay attention to the election while the respondents themselves who answered always follow the election discourse there are 8 people. Can be concluded if 5 people among the respondents affected by the environment in terms of following the election discourse.

An alternative explanation of why there are 5 people who are not affected by the environment in their attention to the election can be traced from the respondent's answer about whether they are following the news about the election in the mass media. As many as 6 people (12\%) answered always, 13 people (26\%) answered frequently, 20 people (40\%) answered 
rarely and 11 people (22\%) answered never. The above data provides an alternative explanation from which some people who are not affected by the environment get attention to the election from the mass media. There are 6 people who always and 13 people often follow the election discourse in the mass media. Furthermore, the most mass media used as a source of election information is the television that is as many as 17 people and internet / social media as many as 16 people, while the rest do not give an answer.

The number of respondents who watch television is actually far more than 17 people, only the spectacle is not related to the election. It is revealed from the respondent's answer to the question of how long they watch television in a day. There are 30 people who watch for 1-2 hours a day, 9 people to watch for 3-4 hours a day, 5 people watch for 5-6 hours a day, 5 people never watch TV and 1 person does not give answer. The most widely accessible TV broadcasts of respondents in a day is quite diverse. 6 respondents watched more TV One shows, 7 more respondents watched the show on Metro TV, 8 more respondents watched the show on SCTV, 2 more respondents watched the show in ANTV, 2 respondents watched more at the event at Compass TV, 8 respondents watched more events in RCTI, 8 respondents watched more events in Indosiar, 3 respondents watched more shows on NET TV, and the rest gave no answer. The most watched shows of the day are also quite diverse. 2 respondents watched more events Infotaiment, 11 respondents watched more news events, 1 respondent watched more music shows, 21 respondents watched more Sinetron / FTV shows, 2 respondents watched more sporting events, 6 respondents more often watch talksow show, and the rest do not give answer.

Media other than television accessed by respondents ie radio, newspapers and internet. Of the 50 respondents, only 3 of them listened to the radio. All three listen to RRI about 1-2 hours a day. Newspapers are only read by 10 respondents. 6 of them read Fajar newspaper, 2 people read Tribune East and 2 others read Kompas newspaper. Internet media accessed by 26 people with a fairly diverse intensity. 6 people access the internet 1-2 hours a day, 7 people access internet 2-4 hours a day, 6 people access internet 5-6 hours a day, 2 people access internet 7-8 hours a day, 5 people access internet above 8 hours a day, the rest not access the internet. Social media accessed by majority respondents is Facebook that is as much as 18 respondents, whatsapp 6 respondents and BBM 1 person. The rest do not access social media.

Political socialization is the pattern and processes by which individuals engage in political development and learning, constructing their particular relationships to the political contexts in which they live [2]. So political socialization talks about a process whose ultimate goal is involvement in politics. The context of this research is the politics that discusses the general election. At the time of the study, Selayar District was not in any election stage except for the election of village heads in several villages. Therefore, the involvement in the election is measured by the process of the community following the development of the general election discourse.

It has been described that work and education factors appear to influence the intensity of the public's attention to electoral discourse. Fishermen, seafarers and merchants are the fewest jobs to keep up with elections. The first two professions mentioned are purely in touch with the maritime sector. Fishermen and seafarers based on the characteristics of their work require them to be more at sea and on the move. This can be understood as one of the reasons why they are not so concerned about the election. The traders who become the majority respondents such as fish traders so that they also have a close relationship with the maritime sector. Fish sales activities in Selayar regency are usually morning and evening. During fish sales activities, they certainly do not have the opportunity to take care of anything other than serving the buyer. This condition can be the reason why fish traders pay less attention to the election.

There are five political dissemination agencies according to Rush and Althoff that is family, school, peer groups, mass media and government [3]. The results show that if families, schools, peer groups and mass media do not support respondents to follow the development of electoral discourses. Among the four agencies, the identified family discussed at least the development of election discourse and the mass media discussing the most election discourse. In the case of families as agents of political socialization, in many literatures it is explained that the family is the main agent in the process of imitation of political socialization. Children learn on their parents about political behavior and attitudes. So the family is more involved in the affective sphere while the discourse around the election is a cognitive domain that was not much discussed in the family especially when not in the atmosphere of elections. In the family more discussed simple things such as how the achievements of children to gossip about citizens in the neighborhood [4]. If within the family of discourse can be freely controlled by the family itself, in the context of mass media discourse can not be controlled by other than the media itself. That is the reason why among the four mass media socialization agencies that have the greatest role in supporting respondents to follow the development of electoral discourses. Not only support, mass media can be considered to force the public to pay attention to the election discourse. Because, without being asked any occasionally audiences for example suddenly displayed news about the general election through breaking news. In addition to television, social media is the most accessible medium of society. Unfortunately this media has not been maximized by the organizers or election participants.

Striked by the lack of discussion of political discourse in peer society and in the workplace it is closely related to money politics. Budiman explains that before the last elections, the public still discussed many political issues [5]. But after the elections they became afraid to discuss the election because there was once the intimidation of certain parties to return the money "attack dawn" that has been given. Not a few people who do receive money from all candidates but do not vote so that some feel harmed and keep looking for people who do like that. For that reason the community no longer dare to discuss all things that smell elections in the environment. We also find it difficult to find respondents especially if there is a question about money politics. 


\section{CONCLUSION}

If using the final outcome indicator is public attention in the general election then in the year no elections as of 2017, there is no political socialization media that significant role in socialization about the general election. Recorded public attention to election wardens only about $34 \%$. Of the $34 \%$ of respondents who pay attention to the election, the mass media still holds the greatest role in influencing the public in paying attention to the discourse around the election. The least influence in the form of citizens' attention to the election discourse is the family.

\section{REFERENCES}

[1] A.G.Kadir, Nurlinah, and J. Nas, "Identification of Voting Behavior on Direct Election of Pilkada in Maritime Regions in South Sulawesi,” The Social Science. vol. 12. Issu 10, 2017.

[2] I. Sapiro, "Not Your Parents' Political Socialization: Introduction for a New Generation,” Annual Review of Political Science, vol. 7: 1-23. Virginia, 2004.

[3] M. Rush and P. Althoff, "Pengantar Sosiologi Politik”Jakarta: Rajawali Press, 2002.

[4] Interview with Sulemang, July 2017.

[5] Interview with Budiman, July 2017. 